\title{
Cyanobacterial dynamics and toxins concentrations in Lake Alto Flumendosa, Sardinia, Italy
}

\author{
Mara Stefanelli, ${ }^{1,2}$ Simona Scardala, ${ }^{2}$ Piera Angela Cabras, ${ }^{3}$ Andrea Orrù, ${ }^{3}$ Susanna Vichi, ${ }^{2}$ Emanuela Testai, ${ }^{2}$ Enzo Funari, ${ }^{2}$ \\ Maura Manganelli ${ }^{*}$
}

${ }^{1}$ INAIL (National Institute for Insurance against Accidents at Work), Via Roberto Ferruzzi 38/40, 00143 Rome; ${ }^{2}$ Istituto Superiore di Sanità (National Health Institute), Department of Environment and Health, Viale Regina Elena 299, 00161 Rome; ${ }^{3}$ Istituto Zooprofilattico Sperimentale della Sardegna (Experimental Zootechnic Institute of Sardinia), Via Fratelli Kennedy 2, 08100 Nuoro, Italy

*Corresponding author: maura.manganelli@iss.it

\begin{abstract}
Seasonal blooms of cyanobacteria (CB) are a typical feature of Lake Alto Flumendosa (Sardinia, Italy). The waters of this lake are used for drinking water supply, for agricultural and industrial uses, and fish farming activities. Since cyanotoxins are not monitored in edible organisms, diet could be a relevant route of human exposure. CB also represent a threat for the health of wild and domestic animals that use lake water for beverage. Therefore, to characterize the CB community and assess the risk for human and animal population, $\mathrm{CB}$ dynamic, $m c y \mathrm{~B}^{+}$fraction, and microcystins (MCs) concentration have been followed monthly for 18 months, in three stations. Results confirmed the presence of several toxigenic species. Planktothrix rubescens dominated between August 2011 and April $2012\left(3.5 \times 10^{6}\right.$ cells L $\left.{ }^{-1}\right)$, alternating with Woronichinia naegeliana $\left(8 \times 10^{6}\right.$ cells $\left.\mathrm{L}^{-1}\right)$ and Microcystis botrys $\left(9 \times 10^{5}\right.$ cells $\left.\mathrm{L}^{-1}\right)$. Dolichospermum planctonicum was always present at low densities $\left(10^{4}\right.$ cells $\left.\mathrm{L}^{-1}\right)$. MCs were detected, at values well below the $1 \mu \mathrm{g} \mathrm{L}{ }^{-1}$ threshold of WHO for drinking water. The molecular analysis of $m c y \mathrm{~B}$ gene for P. rubescens indicated the presence of a persistent toxic population (average $0.45 \mathrm{mcyB} / 16 \mathrm{~S}$ rDNA). Highly significant linear regressions were found between $P$. rubescens and the sum of the demethylated MC variants, and between M. botrys and the sum of MC-LR and MC-LA, also when co-occurring, suggesting that these two species were responsible for different MC patterns production. The regression lines indicated a quite stable MC cell quota. However, in some spotted samples very different values were obtained for both MC concentrations and cell quota (from 10-fold lower to 30-40-fold higher than the 'average') showing an unexpected significant variability in the rate of toxin production. The relatively low cell densities during the monitoring period is consistent with the low-to absent MC contamination level found in trout muscle; however, the analytical method was affected by low recovery, probably due to MC-protein binding. Our results show that, during the study period, no risk of exposure for the human and animal population occurred. However, the persistence of a complex CB community characterised by a significant toxic fraction suggests the need for periodic monitoring activity. Particularly, the hidden deep summer P. rubescens blooms, located where water is taken for drinking water supply, and $M$. botrys, able to produce the most toxic MC variants with high cell quota, should be kept under control. The documentation and interpretation of sudden changes in toxins concentrations deserve special attention. This is particularly relevant in proximity of fish farming plants and water catchment sites.
\end{abstract}

Key words: Toxic cyanobacteria; cyanotoxins; microcystins; human and animal exposure; health risk.

Received: 19 October 2016. Accepted: 3 March 2017.

\section{INTRODUCTION}

Cyanobacteria are a common and naturally occurring component of freshwater environments, although they can be found in all terrestrial and aquatic ecosystems (Whitton, 2012). They are important primary producers and play a key role in ecosystem functioning and biodiversity. However, they can pose risks to environment and aquatic consumers through the production of cyanotoxins (CTX), a large group of toxins that comprise microcystins (MCs), which are the most numerous and studied chemical variants (Buratti et al., 2017). During dense blooms, which are increasingly occurring due to eutrophication and climate changes (Paerl and Paul, 2012; Planas and Paquet, 2016), CTX can reach very high concentrations, affecting both humans and aquatic animals, as well as wild and livestock animals (Funari and Testai, 2008; Moreira et al., 2013; Hilborn and Beasley, 2015; Testai et al., 2016b; Wood, 2016; Buratti et al., 2017). Reports of animal poisonings attributable to CTX have been documented worldwide for more than a century. A diverse range of animals has been affected - from dogs, cattle and fish, to flamingos, bats and bees (Carbis et al., 1995; Frazier et al., 1998; Briand et al., 2003; Stewart et al., 2008). Some animals appear to be attracted by cyanobacteria in water and dried crusts on top of the water, even when clean water was plainly accessible (Codd et al., 1992; Lopez Rodas and Costas, 1999). Oral human exposure to CTX can occur through the ingestion of drinking water from a contaminated source or through the ingestion of inadver- 
tently swallowed contaminated water during recreational activities (Funari and Testai, 2008; Testai et al., 2016a). Furthermore, humans can be orally exposed through the ingestion of cyanobacteria-based food supplements (Saker et al., 2005; Vichi et al., 2012) or food items such as fish and shellfish with bioaccumulated toxins (e.g., through filtration of contaminated water) (Ibelings and Chorus, 2007; Berry, 2013). Additional routes of exposure are dermal contact and accidental inhalation during recreational activities in waters subjected to a toxic bloom.

In Sardinia, more than $90 \%$ of the drinking water originates from artificial lakes which are generally eutrophic (Lugliè et al., 2013), the ideal environment for cyanobacterial blooms. Indeed, cyanobacteria have become dominant in many reservoirs over time (Sechi and Lugliè, 1992, 1996; Aktan et al., 2009; Pulina et al., 2011). However, only a few studies have assessed the presence of CTX, namely MCs (Messineo et al., 2009; Sulis et al., 2014; Mariani et al., 2015). Furthermore, a toxic strain of Microcystis aeruginosa (Kützing) Kützing, associated with a fish kill event, was isolated in Lake Liscia (Pellegrini et al., 1995), and a toxic bloom of Planktothrix rubescens (formerly Oscillatoria rubescens) (de Candolle ex Gomont) Anagnostidis and Komárek was documented in 1986 in the Flumendosa reservoir (Loizzo et al., 1988). In the last 30 years, the Flumendosa reservoir has been used as the main water supply for civilian, agricultural and industrial uses in Southern Sardinia (Botti et al., 2001). In addition, a trout farming plant is located nearby, whereas water is utilised also by wild animal and livestock for beverage. In the 1990s, Cyanophyceae, together with Bacillariophyceae and Chlorophyceae, were the dominant classes in the Flumendosa reservoir system (Lugliè et al., 1997), with CB representing $90-100 \%$ of phytoplankton since 2002 (Sulis et al., 2014). The CB with the highest density described so far are the Planktothrix and Microcystis genera, which have been responsible for the most frequent onset of blooms, while the Dolichospermum genus, except for a bloom in 2003, appeared sporadically (Sulis et al., 2014). To our knowledge, data on MCs in this lake have been assessed only in two occasions and were associated with the presence of $P$. rubescens (Messineo et al., 2009; Sulis et al., 2014). A recent 18-month study on four reservoirs in Northern Sardinia showed significantly different seasonal variations in $\mathrm{CB}$ community composition, with several toxigenic species, and large variability in MCs concentrations (Mariani et al., 2015). The results highlighted the need to increase the knowledge of these aspects in each reservoir, whose use could affect human and animal health. In June 2010, a mass mortality of fish occurred in the Flumendosa reservoir, concurrently with an extensive surface bloom of P. rubescens. The cause for fish mortality was potentially attributed to a combination of oxygen deficiency and CB toxins. Following this event, our study was aimed: i) to characterize the
CB community of the reservoir; ii) to verify the applicability of a linear model used in single species blooms to predict their toxicity (Salmaso et al., 2014); and iii) to assess the potential risk for humans and animals. We followed the dynamics of cyanobacteria for 18 months and determined MCs concentrations, toxicity profile (MC variants concentration), frequency of toxic genotype and accumulation of MCs in farmed trout.

\section{METHODS}

\section{Description of the site and sampling strategy}

The reservoir of the Alto Flumendosa, located in centre-eastern Sardinia (Italy) (latitude: $39^{\circ} 42^{\prime} 38^{\prime \prime} \mathrm{N}$; longitude: $9^{\circ} 17^{\prime} 25^{\prime}$ " E) (Fig. 1), is an artificial lake (volume $64 \times 10^{6} \mathrm{~m}^{3}$ ) with a surface area of $9 \mathrm{~km}^{2}$ (Begliutti et al., 2007) and a maximal depth of around $50 \mathrm{~m}$. It is a complex and multiuse water system, which interconnects with other reservoirs (Flumendosa-Campidano). The reservoirs are linked in a cascading sequence and from each one pressure pipelines and open channels guarantee water for residential use and irrigation of the Campidano plain (Sechi and Sulis, 2009). Once used for the production of electrical energy in three underground stations, the water is conveyed through a system of tunnels in the Lake Teaula, about $286 \mathrm{~m}$ asl, east of Villagrande. At this point, waters are directed through the Tortolì flat for irrigation and for civilian uses (e.g., drinking water) (Cabras et al., 2013).

Water samples were collected in three sites: (1) Zattere (maximum depth $50 \mathrm{~m}$ ) at about $10 \mathrm{~m}$ from a trout's floating cages farming plant; (2) Middle site in the centre of the lake (maximum depth $25 \mathrm{~m}$ ), in front of the water offtake site (collecting water also for drinking purposes); and (3) Rio Osiana (maximum depth $7 \mathrm{~m}$ ) close to the inflow of a small temporary tributary stream (Fig. 1). During our sampling period (October 2011 - May 2013), the stream periodically underwent dry phases. After Oct 2012, the site 3 was no longer sampled, since the values of the studied parameters were not different from the other sites. Since in some periods some CB species density was very low, two different strategies of sampling were used to monitor their temporal dynamics: i) discrete samples were collected monthly in the whole sampling period (18 months) in the three stations at the surface (S1, S2, S3) and in the stations 1 and 2 at $20 \mathrm{~m}$ depths (P1, P2; depth of the water offtake site, which is important to check when P. rubescens occurs) (Manganelli et al., 2016) using a Van Dorn bottle; ii) periodically, integrated samples were collected with a $20 \mu \mathrm{m}$ phytoplankton net on a water column of $30 \mathrm{~m}$ (R1), $25 \mathrm{~m}$ (R2) and $7 \mathrm{~m}$ (R3). Samples were collected and stored in acid clean polycarbonate bottles, in cold and dark conditions until the arrival in the laboratory where they were aliquoted for the different analysis. 
Five fish samples were collected from November 2011 to September 2012, every two-three months, from the trout farming plant (2-3 animals for sampling).

\section{Physical measurements and chlorophyll-a analysis}

Chlorophyll-a (Chl-a) was extracted according to Jespersen and Christoffersen (1987). Samples were filtered onto GF/F filters (Whatman) and stored in 96\% ethanol in the dark at room temperature over-night. The fluorescence of the extract was measured with a TURNER 10AU-005 fluorimeter (Holm-Hansen et al., 1965). Temperature was read from a thermometer inside the sampling bottle, as soon as the sample arrived at the surface, and $\mathrm{pH}$ was measured in the field with a $\mathrm{pH}$ meter probe.

\section{Cyanobacteria abundance and isolation}

Cyanobacteria taxonomic determination was carried out according to Komárek and Anagnostidis $(1999,2005)$ and Komárek and Zapomělová (2007). Cyanobacteria abundance was determined by epifluorescence microscopy, since phycoerythrin and phycocyanin contained in $\mathrm{CB}$, when examined under blue light excitation, fluoresce orange and red, respectively (Walsby and Avery, 1996; Ernst et al., 2006). This technique, based on sample concentration on filters, allows the concentration of large volumes in few minutes and the counts of species present within a large range of densities (Hallegraeff et al., 2004). Fifty $\mathrm{mL}$ of formaldehyde-fixed samples (final concentration 4\%) were filtered onto $5 \mu \mathrm{m}$ black membrane filters ( $25 \mathrm{~mm}$ diameter) (Whatman). The number of filaments and colonies was counted by autofluorescence under blue light with an upright microscope (Olympus BX51) at 100x. Two replicate filters per sample were counted, with a variation between filters generally well within $20 \%$. The number of cells per filament/colony was determined by average on 50 filaments/colony on both filters, using an image analysis software (ImageJ, http://rsbweb.nih.gov/ij/).

Monoclonal strains of $P$. rubescens were isolated as follows. The filaments were plated on BG-11 medium 1\% agar (DIFCO) plates. The plates were then incubated at $14^{\circ} \mathrm{C}$, at a photosynthetic photon flux density of $10 \mu \mathrm{mol}$ $\mathrm{m}^{-2} \mathrm{~s}^{-1}$ in a light:dark cycle $(16: 8 \mathrm{~h})$. Filaments were isolated by micromanipulation according to Rippka (1988)

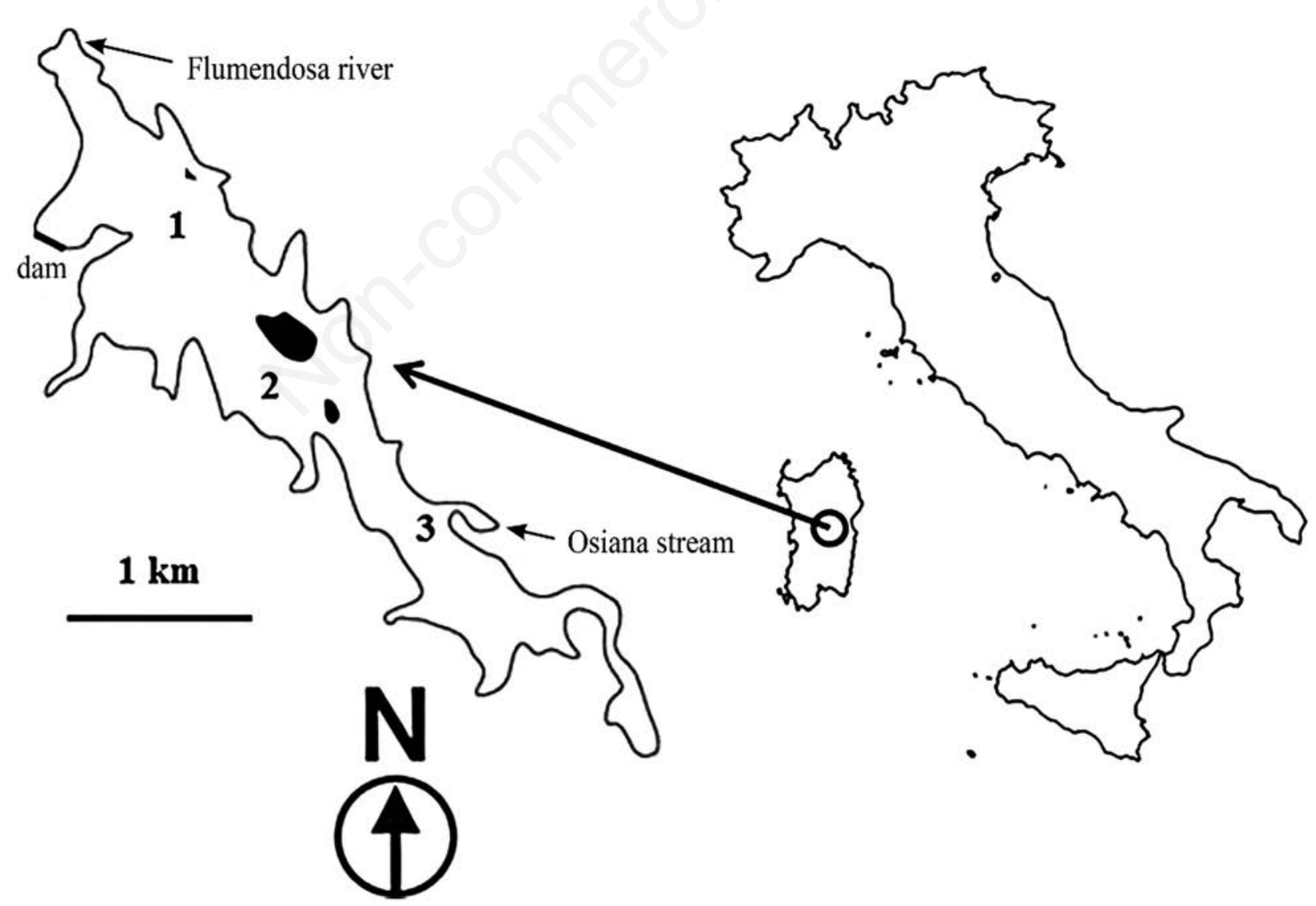

Fig. 1. The Flumendosa reservoir and sampling sites. 
and incubated at the same conditions described above, in liquid BG-11 medium. We also tried to isolate colonial cyanobacteria, like Woronichinia naegeliana (Unger) Elenkin, as described by Sedmak et al. (2008). The samples were concentrated in test tubes under natural light. Colonies floated towards the surface due to their buoyancy mechanism. The remaining phytoplankton together with zooplankton sank to the bottom. The surface layer with cyanobacterial material was collected and re-examined by microscopy resulting monospecific (over 99\%). The colonies were then incubated in liquid BG-11 at the same conditions as above. However, all isolation attempts failed. W. naegeliana did not persist in culture more than one month and no further analysis was carried out.

\section{Phytoplankton abundance}

Samples for the identification and counting of phytoplankton other than cyanobacteria were fixed with formaldehyde (final concentration 4\%) and/or Lugol's solution (final concentration 1\%). Ten $\mathrm{mL}$ samples were sedimented according to the Utermhöl method (1958) and counted under an inverted microscope (Olympus IX50) at 40x and 400x magnification, in bright-dark field.

\section{Detection of microcystins}

\section{ELISA}

Total (intra- and extra-cellular content) MCs were analysed in untreated water samples by an enzyme-linked immunosorbent assay (ELISA). After three freeze/thaw cycles, the samples were analysed using an ELISA kit (Microcystins ADDA-ELISA Microtiter Plate, ENVIROLOGIX, Portland, ME, USA) according to the manufacturer's protocol. Microscope observation of freeze thawed samples confirmed the complete lysis of cells. The results were expressed as MC-LR equivalents (MC-eq). Methanol extracts from fish samples were also tested, after being dried and re-dissolved in water, with minor modification from Papadimitriou et al. (2012). Briefly, 5 $\mathrm{g}$ of fish muscle from each animal were added with $10 \mathrm{~mL}$ methanol, homogenized, centrifuged at $4000 \mathrm{rpm}$ for 10 $\mathrm{min}$ and the supernatant collected. The extraction step was repeated twice and the supernatant fractions were pooled. Three aliquots of $5 \mathrm{~mL}$ each were gently evaporated to dryness at $45^{\circ} \mathrm{C}$ in rotavapor. The residue was reconstituted in $500 \mu \mathrm{L}$ of distilled water. Samples were considered positive when the $\mathrm{MC}$ concentration was higher than the detection limit of the method $\left(0.10 \mu \mathrm{g} \mathrm{L}^{-1}\right)$.

\section{LC-MS/MS analysis}

To discriminate the different $\mathrm{MC}$ variants, which have a different toxicity (Funari and Testai, 2008; Buratti et al., 2017), samples have also been analysed by liquid chro- matography tandem mass spectrometry (LC-MS/MS). The extraction procedure was different for water samples and complex matrix as tissues.

\section{Water samples}

Each sample was divided into two $500 \mathrm{~mL}$ aliquots: one was used to determine dissolved MCs and one to determine total MCs. For dissolved fraction detection, samples were filtered onto $\mathrm{GF} / \mathrm{C}$ discs (Whatman) in order to eliminate cells. The filtrate, acidified, was cleaned-up by solid-phase extraction (SPE), as previously described (Buratti et al., 2011). Briefly, samples were purified and concentrated through ODS SPE cartridge, rinsed with $20 \% \mathrm{MeOH}$ (4 $\mathrm{mL}$ ), then eluted with $4 \mathrm{~mL} \mathrm{MeOH}$. The eluate was dried under a gentle nitrogen stream, and re-dissolved in $0.5 \mathrm{~mL}$ of acetonitrile:water (30:70) containing $0.1 \%(\mathrm{v} / \mathrm{v})$ formic acid. To determine total MCs (dissolved plus intracellular $\mathrm{MCs}$ ), the aliquot was freeze-thawed three times, to cause cell lysis with the consequent release of intracellular CTX and then treated as described above for the dissolved fraction. The intracellular content of MCs was calculated as the difference between total and dissolved concentration.

\section{Fish}

Fish tissues have been extracted as reported above for ELISA assay.

Separation, identification and quantification of the MC variants (MC-LR, -LA, -YR, -RR, -LF, -LW, -demLR, -dem-RR, for which standards were available) were performed with two MicroPump and an autosampler PE series 200 (Perkin Elmer Inc., Waltham, MA, USA), coupled to a triple-quadrupole mass spectrometer equipped with a TurboIonSpray source (MDS Sciex, Concord, Canada). MS tuning and optimization were achieved by infusing MCs standards (Alexis, San Diego, CA, USA); detection was carried out using Multiple Reaction Monitoring (MRM) mode. MCs separation, in MRM analysis, was conducted as previously described (Buratti et al., 2011). All samples were run in MRM mode, utilizing the specific fragmentation reaction of single or doubly protonated MCs to $\mathrm{m} / \mathrm{z}$ 135, the specific fragment associated to the Adda fragment. The amount of MCs was quantified by the external standard quantification procedure, referring to a calibration straight line with 4-6 known amounts of the analytical standards in solvent (coefficient of determination, $R^{2} \geq 0.98$ ), for water samples, and in the blank fish matrix, for fish samples, in order to exclude any interference due to matrix effect. Indeed, salts that are hardly removed during extraction procedures and sample preparation may influence samples ionization, causing a quenching of the signal for some congeners whereas for others the signal can be overcompensated (Vichi et al., 2012). In fish samples, recovery was also investigated 
spiking pre- and post-extraction with known amounts of standard MCs. We found around $80 \%$ recovery for the different MC variants tested, except for MC-RR, MC-demRR and MC-LA, for which recovery was never higher than $50 \%$. For the applied method, the LOQ ranged between $2 \mathrm{ng} \mathrm{L} \mathrm{L}^{-1}$ (MC-RR) and $9 \mathrm{ng} \mathrm{L^{-1 }}$ (MC-LW) for water samples, and between $5 \mathrm{ng} \mathrm{g}^{-1}$ (MC-LR) and $15 \mathrm{ng} \mathrm{g}^{-1}$ (MC-LF) for fish samples.

\section{Molecular investigation}

Each field sample $(250-500 \mathrm{~mL})$ was filtered on 0.2 $\mu \mathrm{m}$ Supor Membrane Filters to harvest the cells; filters were stored at $-20^{\circ} \mathrm{C}$. Total genomic DNA was extracted using the commercial DNeasy plant mini kit (Qiagen), following the manufacturer's instructions. Genomic DNA concentration was measured by a biophotometer (Eppendorf), and purity was assessed by calculating the ratio of the absorbance at $260 \mathrm{~nm}$ and $280 \mathrm{~nm}$.

Molecular analyses were performed exclusively on 83 samples, where the $P$. rubescens cells abundance, estimated by counting before storage and DNA extraction, exceeded or was equal to the threshold of $10^{4}$ cells $\mathrm{L}^{-1}$, in order to obtain reliable and consistent results.

A preliminary qualitative PCR was carried out to identify the MC-producing genera Planktothrix and Microcystis, following the methods of Rantala et al. (2006) and Vaitomaa et al. (2003), based on the detection of the genus-specific $\mathrm{MC}$ synthetase gene $\mathrm{E}(m c y \mathrm{E})$. The quantitative estimation of Planktothrix cells and the fraction of individuals carrying MCs biosynthesis genes were further investigated by qPCR employing a StepOne ${ }^{\mathrm{TM}}$ RealTime PCR System (Applied Biosystems), according to Ostermaier and Kurmayer (2009). Two independent Taq Nuclease Assays (TNAs) were used, one to quantify the general population of Planktothrix using the 16S rDNA region as specific genus marker, and the other one to quantify the potential MC-producing genotypes within the community by checking the amplification of the first adenylation domain of $m c y \mathrm{~B}$ ( $m c y \mathrm{BA} 1)$.

Genotypes of the unknown samples were quantified relating their threshold cycle $(\mathrm{Ct})$ to the starting cell concentration, by applying the standard curve methodology. For both $16 \mathrm{~S}$ rDNA and $m c y \mathrm{~B}$ genes the standard curves were established using serial dilutions of DNA extracted from known cell concentrations of $P$. rubescens strains CCAP1460/3 and CCAP1460/10. The serial dilutions and the samples were amplified simultaneously to determine their $\mathrm{Ct}$ values under the same experimental conditions. Each measurement was performed in triplicate.

A similar qPCR approach was applied to quantify the toxic fraction of Microcystis (Vichi et al., 2012); however, some cross reactivity was observed when primers were tested in the presence of $W$. naegeliana cells, which often co-occurred with Microcystis in the environmental sam- ples, thus making this method unreliable for the quantitative estimation of Microcystis $m c y^{+}$cells.

\section{Statistics}

Differences between set of data were tested with ANOVA, with the software STATISTICA 6 (StatSoft, Inc. OK, USA), after testing for normality. Since data from surface sampling sites were not statistically different they have been averaged and average \pm SD has been considered. Correlation analysis between different variables has been calculated with the software SigmaPlot 9.01 (Systat) on all raw data.

\section{RESULTS}

\section{Temperature}

Data of temperature are shown in Fig. 2. The lake was generally stratified from March-April until December.

\section{Cyanobacteria abundance and isolation}

Several potentially toxic species were detected during the monitoring period, with a variable relative abundance over the year: Planktothrix rubescens, Woronichinia naegeliana, Microcystis botrys Teiling and Dolichospermum planctonicum (Brunnthaler) Wacklin, L. Hoffmann \& Komárek (Fig. 3).

P. rubescens was always present (Fig. 3a); it dominated in both surface and $20 \mathrm{~m}$ depth samples, from November 2011 to summer months in 2012, being significantly lower in the remaining months. During the stratification period, with surface temperatures reaching a maximum of $22.5^{\circ} \mathrm{C}$, the highest densities were at $20 \mathrm{~m}$ depth, with values oscillating between 1.5 to a maximum of $5 \times 10^{6}$ cells $\mathrm{L}^{-1}$, according to the typical seasonal dy-

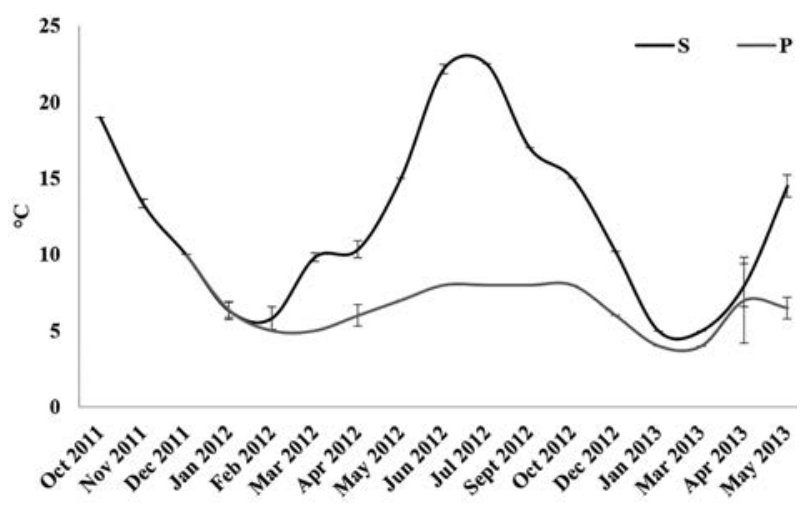

Fig. 2. Temperature variation at the surface $(S$, average of the 3 surface sites $\pm \mathrm{SD}$ ) and $20 \mathrm{~m}$ depth $(\mathrm{P}$, average of the 2 depth sites \pm SD). Aug 2012, Nov 2012, Feb 2013 no sampling. 
namic of this species. After July 2012, P. rubescens density was about one order of magnitude lower than in the previous year (Fig. 3a). During the stratified period, sporadic samples in $\mathrm{S} 1$ were collected every $5 \mathrm{~m}$ from surface to $-20 \mathrm{~m}$, confirming that $P$. rubescens was homogenously distributed between -10 and $-20 \mathrm{~m}$ with higher density than surface (data not shown).

$W$. naegeliana was numerically dominant from September to December 2012 when it reached high values on the surface (4.3-7.5 $\times 10^{6}$ cells $\left.\mathrm{L}^{-1}\right)$ and at $20 \mathrm{~m}$ depth (6$8 \times 10^{6}$ cells $\mathrm{L}^{-1}$ ), that is about one order of magnitude higher than in 2011 (Fig. 3b). In the remaining months, it was totally absent or present at much lower densities.

$M$. botrys was found from the beginning of the monitoring activity until January 2012 and from May to October 2012 in surface samples and sporadically in depths samples (Fig. 3c). A peak of density (up to $8 \times 10^{5}$ cells L ${ }^{-1}$, sites $\mathrm{S} 1$ and S2) was observed in October 2011 at the surface, when it represented the dominant species among CB (45\%); it sharply decreased to less than $5 \%$ of total CB community in the following months.

D. planctonicum was always present at low densities (Fig. 3d). In surface samples, it never exceeded $4 \times 10^{4}$ cells $\mathrm{L}^{-1}$; densities at depths were similar or lower. The lowest values were measured in samples collected in 2013.

When integrated samples were considered, $M$. botrys

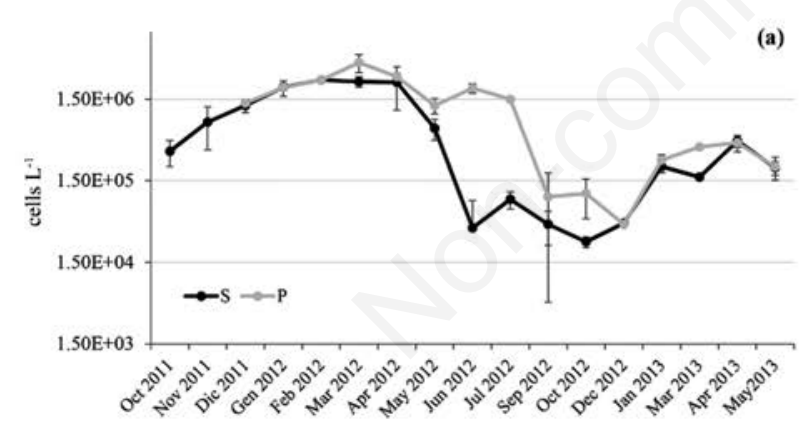

(c)

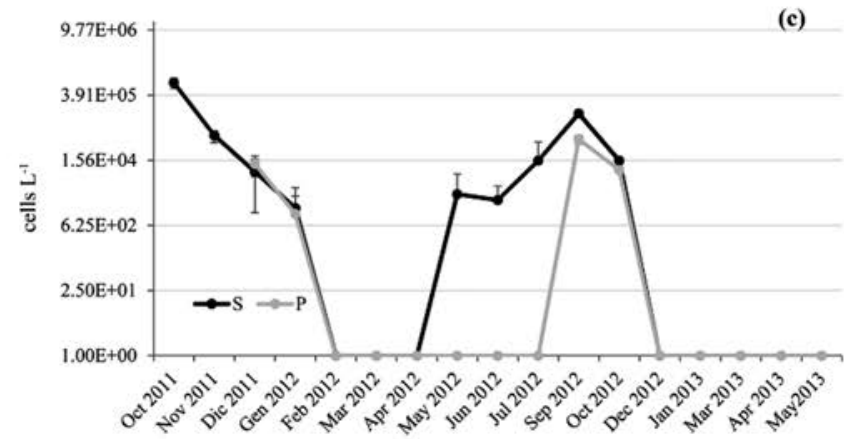

was the only species virtually absent from the lake between December 2012 and May 2013, when it was again detectable at very low density $\left(1.7 \times 10^{4}\right.$ cells $\left.\mathrm{L}^{-1}\right)$ although only in R2 (Tab. 1). P. rubescens and W. naegeliana were always present at very high density (up to $1.5 \times 10^{9}$ cells $\mathrm{L}^{-1}$ and $2.4 \times 10^{9}$ cells L $\mathrm{L}^{-1}$ respectively). D. planctonicum was characterized by low densities (maximum $7 \times 10^{6}$ cells $\mathrm{L}^{-1}$ ).

\section{Phytoplankton abundance}

The phytoplankton community showed a high variability in both cell abundance and species composition. It consisted of green algae like Chlorella sp., Scenedesmus sp. and Chlorococcum sp., and diatoms like Aulacoseira sp., Fragilaria sp. and Asterionella sp. In terms of cell number, they represented on average only $\sim 30 \%$ of the community (median $=15 \%$ ). However, their biomass was more relevant. Indeed, two significant correlations, one for summer and one for winter $(\mathrm{r}=0.73 \mathrm{P}<0.001$ and $\mathrm{r}=0.90 \mathrm{P}<0.001$, respectively), identified by two ranges of temperature, were found between the density of the whole phytoplankton community (CB and algae) and Chla, used as a proxy for biomass (Fig. 4). Excluding non$\mathrm{CB}$ algae from the number of cell data, correlations were no longer significant, implying that in this lake, even if
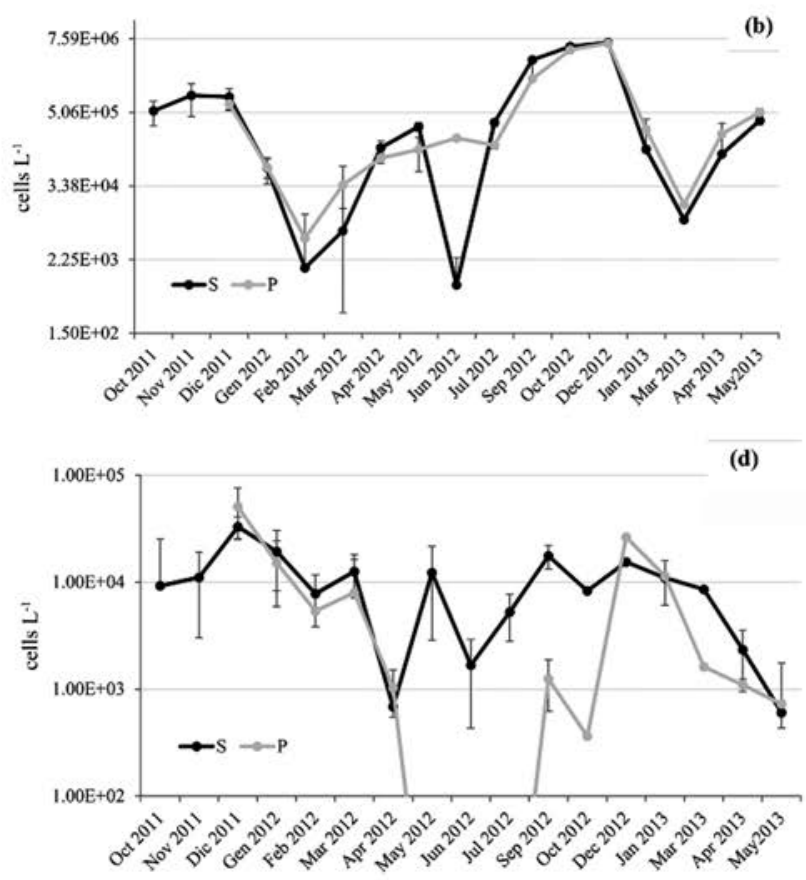

Fig. 3. Seasonal variations in the densities of (a) P. rubescens, (b) W. naegeliana, (c) M. botrys and (d) Dolichospermum sp. at the surface (S, average of the 3 surface sites \pm SD and at $20 \mathrm{~m}$ depth (P, average of the 2 depth sites \pm SD) (Y axis log scale). Aug 2012, Nov 2012, Feb 2013 no sampling. 
$\mathrm{CB}$ were numerically more abundant than algae, Chl-a could not be used as an index of CB abundance.

\section{Detection of microcystins}

\section{ELISA}

The MCs concentrations in water were always detected in the range $0.1-1 \mu \mathrm{g} \mathrm{L}^{-1}$ (data not shown). The highest values were found in October 2011 in a surface sample, when the dominant species was M. botrys.

\section{$L C-M S / M S$}

MC-LA, -LR, -dem-LR, -RR, -dem-RR were detected in all samples in different relative proportions, whereas the other tested congeners MC-LF, -LY end -LW were always below the detection limit $\left(9 \mathrm{ng} \mathrm{L^{-1 }}\right)$. Consistently with the ELISA data, in all discrete samples MCs concentrations never exceeded $1 \mu \mathrm{g} \mathrm{L}^{-1}$ (Supplementary Tab. 1). The levels of MCs in integrated samples ranged between 0.4 and $100 \mu \mathrm{g} \mathrm{L}^{-1}$ (Tab. 2). The highest value was measured in May 2012 when a 10-fold difference was observed between R1 and R3, although the relative proportion of the different variants was the same.

The pattern of congeners in both discrete and integrated samples revealed that generally, but not always, MC-dem-RR accounted for $\sim 92 \%$ (up to $100 \%$ ) and MCdem-LR up to $11 \%$, with the sum of the other variants $<1 \%$ (Tabs. 2 and 3). Indeed, in some samples, the pattern of congeners was totally different, with MC-LR and MCLA accounting for $\sim 60 \%$ and $30 \%$, respectively.

The fit of linear models between single congeners and cyanobacterial species allowed distinguishing the potential producers of different MC variants. In discrete samples, highly significant correlations were observed between $P$. rubescens and MC-dem-RR and MC-dem-LR concentration $\left(\mathrm{R}^{2}=0.81\right)$ (Fig. 5a) and between $M$. botrys and MC-LR, -RR, -LA ( $\left.\mathrm{R}^{2}=0.86\right)$ (Fig. 5b). In the integrated samples, no correlation between $P$. rubescens and dem-MC was observed when all data were included in the analysis. Excluding the values measured in May 2012, which deviated from the main pattern, the relationship between MC concentrations and P. rubescens densities was significant $\left(\mathrm{R}^{2}=0.67\right)$ (Fig. 6a), with a slope not different from that obtained from the discrete samples (t-test $\mathrm{t}=0.34, \mathrm{P}>0.5$ ) (Fig. 5a). The correlation between MC-LR and MC-LA and $M$. botrys was still highly significant $\left(\mathrm{R}^{2}=0.94\right)$ (Fig. 6b). Also in this case, the slopes of linear models computed on data measured in discrete and inte-

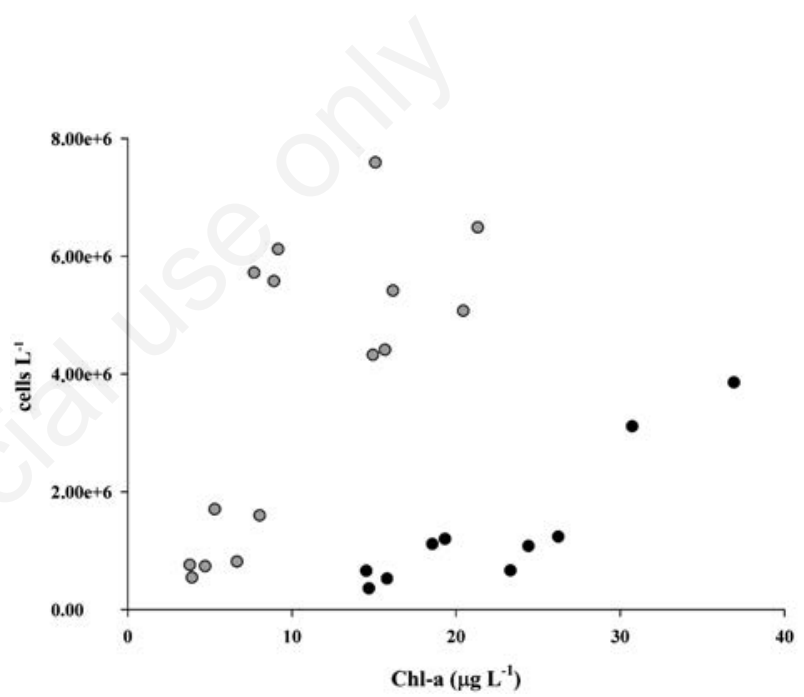

Fig. 4. Variation of number of cells (phytoplankton including cyanobacteria) vs Chl-a in surface sites (Grey, warm season; black, cold season).

Tab. 1. Cyanobacteria density (cells $\mathrm{L}^{-1} \times 10^{6}$ ) in integrated samples in the three sites.

\begin{tabular}{|c|c|c|c|c|c|}
\hline Site & Date & M. botrys & P. rubescens & W. naegeliana & D. planctonicum \\
\hline \multirow[t]{9}{*}{$\mathrm{R} 1$} & Oct 2011 & 52.6 & 7.00 & 36.2 & 2.02 \\
\hline & May 2012 & nd & 181 & 158 & 7.41 \\
\hline & Sept 2012 & 30.8 & 7.40 & 2390 & 0.68 \\
\hline & Oct 2012 & 7.04 & 9.87 & 755 & 0.77 \\
\hline & Dec 2012 & nd & 3.29 & 2150 & 2.51 \\
\hline & Jan 2013 & nd & 50.4 & 118 & 1.55 \\
\hline & Mar 2013 & nd & 94.1 & 13.3 & 0.001 \\
\hline & Apr 2013 & nd & 252 & 355 & 1.31 \\
\hline & May 2013 & nd & 21.8 & 127 & 0.12 \\
\hline \multirow[t]{4}{*}{$\mathrm{R} 2$} & Oct 2011 & 71.9 & 13.1 & 100 & 1.63 \\
\hline & May 2012 & 17.3 & 1510 & 486 & 5.27 \\
\hline & Apr 2013 & nd & 75.8 & 67.3 & 0.12 \\
\hline & May 2013 & 0.02 & 14.8 & 93.3 & 0.07 \\
\hline \multirow[t]{2}{*}{ R3 } & Oct 2011 & 58.6 & 6.76 & 131 & 2.53 \\
\hline & May 2012 & 3.52 & 1350 & 82.9 & 1.50 \\
\hline
\end{tabular}

nd, not detected. 
grated samples were not statistically different $(\mathrm{t}=0.25$, $\mathrm{P}>0.5)$.

During the study, 10 strains of $P$. rubescens were isolated and grown in laboratory conditions. The strains were all toxic, producing only MC-dem-RR $(94 \% \pm 2 \%)$ and dem-LR $(6 \% \pm 2 \%)$.

\section{Detection of MC in fish}

The application of ELISA tests to fish muscle tissues showed a weak contamination of the examined samples (Tab. 4). These results were not confirmed by the LC$\mathrm{MS} / \mathrm{MS}$ analyses that revealed at most not quantifiable traces of MC-LR and MC-dem-LR.

\section{Molecular investigation}

The potential toxigenicity of the two genera Microcystis and Planktothrix was qualitatively confirmed by PCR in some randomly selected integrated samples with high CB cell densities. The environmental samples were amplified together with the reference strains of $M$. aeruginosa and $P$. rubescens, used as positive controls for the presence of the $m c y \mathrm{~B}$ gene. The absence of any cross-reactivity between DNA from Planktothrix and Microcystis and the selected primers was verified and excluded with preliminary PCR assays on each isolated environmental culture; in addition, no PCR product was obtained when the same primers were tested in samples dominated by $W$. naegeliana. No conclusions could be drawn on the potential toxigenicity of the $W$. naegeliana strains present in the lake, since no isolated reference strains (neither discriminating primers) were available.

The quantitative estimate of the toxic genotypes performed on the Planktothrix population by qPCR revealed a permanent and fairly constant fraction (about 40-50\%) of $m c y \mathrm{~B}^{+}$cells throughout the monitoring period, with

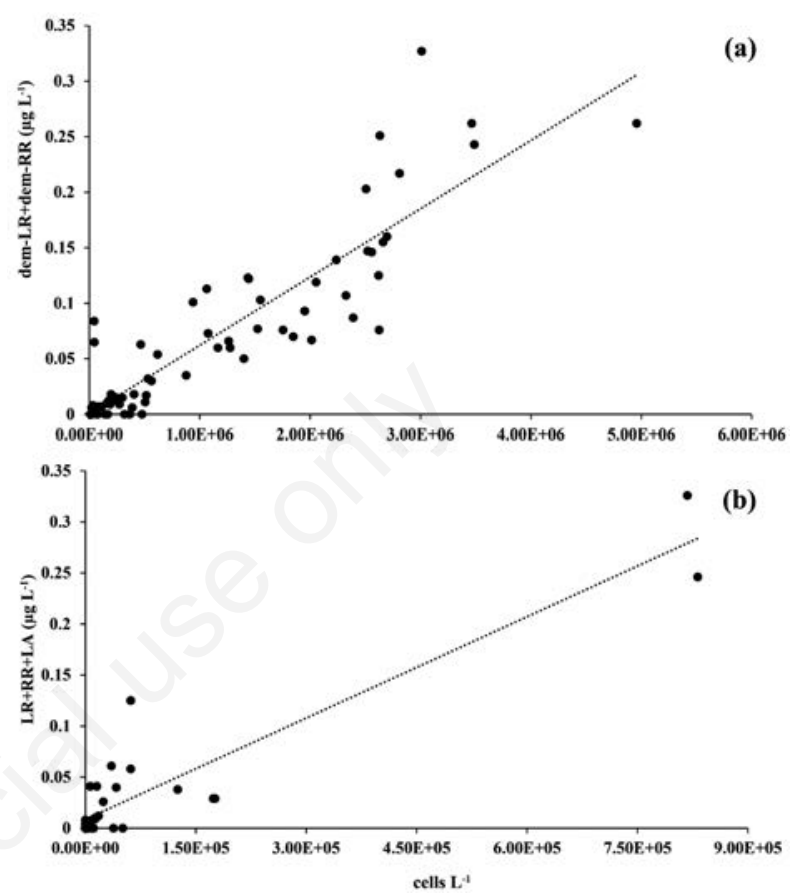

Fig. 5. a) Correlation between $P$. rubescens and MC-dem-LR + MC-dem-RR in discrete samples; the regression line is $\mathrm{Y}=6.17 \times 10^{-8}\left(\mathrm{SE} 3.60 \times 10^{-9}\right) \cdot \mathrm{X}+8.61 \times 10^{-5}\left(\mathrm{SE} 5.65 \times 10^{-3}\right)$; $\mathrm{R}^{2}=0.81, \mathrm{P}<0.001$. b) Correlation between $M$. botrys and MCLR + MC-RR + MC-LA in discrete samples; the regression line is $\mathrm{Y}=3.96 \times 10^{-7}\left(\mathrm{SE} 2.18 \times 10^{-8}\right) \cdot \mathrm{X}+3.68 \times 10^{-3}\left(\mathrm{SE} 3.38 \times 10^{-3}\right)$; $\mathrm{R}^{2}=0.86, \mathrm{P}<0.001$.

Tab. 2. Microcystins concentrations $\left(\mu \mathrm{g} \mathrm{L}^{-1}\right)$ in integrated samples in the three sites.

\begin{tabular}{|c|c|c|c|c|c|c|c|}
\hline \multirow[t]{2}{*}{ Site } & \multirow[t]{2}{*}{ Date } & \multicolumn{6}{|c|}{ Microcystins } \\
\hline & & $\mathbf{R R}$ & dem-RR & $\mathbf{L R}$ & dem-LR & LA & TOT \\
\hline \multirow[t]{9}{*}{$\mathrm{R} 1$} & Oct 2011 & nd & 0.000 & 38.720 & nd & 9.180 & 47.900 \\
\hline & May 2012 & nd & 92.097 & nd & 8.061 & 0.000 & 100.158 \\
\hline & Sept 2012 & nd & 0.865 & 10.381 & 0.266 & 2.573 & 14.085 \\
\hline & Oct 2012 & 0.447 & nd & 4.036 & nd & 1.345 & 5.829 \\
\hline & Dec 2012 & nd & nd & 0.523 & nd & nd & 0.523 \\
\hline & Jan 2013 & nd & 1.449 & 0.043 & 0.102 & 0.044 & 1.638 \\
\hline & Mar 2013 & nd & 4.476 & nd & nd & nd & 4.476 \\
\hline & Apr 2013 & nd & 6.673 & 0.194 & 1.490 & nd & 8.356 \\
\hline & May 2013 & nd & 0.369 & 0.006 & 0.038 & nd & 0.413 \\
\hline \multirow[t]{4}{*}{ R2 } & Oct 2011 & nd & nd & 39.940 & nd & 15.000 & 54.940 \\
\hline & May 2012 & nd & 69.520 & 0.196 & 5.810 & nd & 75.526 \\
\hline & Apr 2013 & nd & 7.383 & nd & 1.372 & nd & 8.755 \\
\hline & May 2013 & 0.012 & 0.692 & 0.015 & 0.057 & nd & 0.775 \\
\hline \multirow[t]{2}{*}{ R3 } & Oct 2011 & nd & nd & 36.070 & nd & 11.880 & 47.950 \\
\hline & May 2012 & nd & 8.338 & 0.221 & 1.181 & nd & 9.740 \\
\hline
\end{tabular}

nd, not detected. 
similar proportions in the surface and deep sampling sites $(48 \pm 19 \%$ vs $40 \pm 15 \%)$, and in integrated samples $(56 \pm 0.18 \%)$.

\section{Cell quota}

Based on the correlations between MC congeners and $\mathrm{CB}$, the toxins cell quota were calculated for $P$. rubescens and $M$. botrys. The cell quota of the dem-MC produced by $P$. rubescens in the discrete samples averaged $0.104 \pm 0.274 \mathrm{pg} \mathrm{MC} \mathrm{cell}^{-1}$ (Tab. 5). The high average and s.d. were due to two values measured in December 2012, S1 and P1, in which the cell quota was 30-40 fold higher than the rest of the values which were quite homogeneous (1.44 and 1.91 vs $0.059 \pm 0.04 \mathrm{pg} \mathrm{MC} \mathrm{cell}^{-1}$ in the remaining samples). When the cell quota was calculated considering only the potentially toxic fraction $\left(m c y \mathrm{~B}^{+} / 16 \mathrm{~S}\right.$

Tab. 3. Percentage of the different microcystins variants in discrete samples.

\begin{tabular}{|c|c|c|c|c|c|c|}
\hline \multirow[t]{2}{*}{ Site } & \multirow[t]{2}{*}{ Date } & \multicolumn{5}{|c|}{ Microcystins } \\
\hline & & $\mathbf{R R}$ & dem-RR & LR & dem-LR & LA \\
\hline \multirow[t]{17}{*}{ S } & Oct 2011 & 0 & 0 & 60 & 0 & 40 \\
\hline & Nov 2011 & 4 & 39 & 44 & 4 & 9 \\
\hline & Dec 2011 & 1 & 79 & 9 & 9 & 1 \\
\hline & Jan 2012 & 0 & 90 & 0 & 10 & 0 \\
\hline & Feb 2012 & 0 & 90 & 0 & 10 & 0 \\
\hline & Mar 2012 & 0 & 91 & 0 & 9 & 0 \\
\hline & Apr 2012 & 0 & 94 & 0 & 6 & 0 \\
\hline & May 2012 & 0 & 100 & 0 & 0 & 0 \\
\hline & Jun 2012 & 0 & 100 & 0 & 0 & 0 \\
\hline & Jul 2012 & 0 & 27 & 9 & 0 & 64 \\
\hline & Sep 2012 & 0 & 16 & 59 & 0 & 25 \\
\hline & Oct 2012 & 0 & 9 & 62 & 0 & 29 \\
\hline & Dec 2012 & 0 & 68 & 24 & 0 & 7 \\
\hline & Jan 2013 & 0 & 100 & 0 & 0 & 0 \\
\hline & Mar 2013 & na & na & na & na & na \\
\hline & Apr 2013 & 0 & 100 & 0 & 0 & 0 \\
\hline & May 2013 & 0 & 100 & 0 & 0 & 0 \\
\hline \multirow[t]{17}{*}{$P$} & Oct 2011 & na & na & na & na & na \\
\hline & Nov 2011 & na & na & na & na & na \\
\hline & Dec 2011 & 2 & 75 & 12 & 9 & 2 \\
\hline & Jan 2012 & 0 & 89 & 0 & 11 & 0 \\
\hline & Feb 2012 & 0 & 92 & 0 & 8 & 0 \\
\hline & Mar 2012 & 0 & 93 & 0 & 7 & 0 \\
\hline & Apr 2012 & 0 & 95 & 0 & 5 & 0 \\
\hline & May 2012 & 0 & 92 & 0 & 8 & 0 \\
\hline & Jun 2012 & 0 & 92 & 0 & 8 & 0 \\
\hline & Jul 2012 & 0 & 92 & 0 & 8 & 0 \\
\hline & Sep 2012 & na & na & na & na & na \\
\hline & Oct 2012 & 0 & 100 & 0 & 0 & 0 \\
\hline & Dec 2012 & na & na & na & na & na \\
\hline & Jan 2013 & na & na & na & na & na \\
\hline & Mar 2013 & 0 & 97 & 3 & 0 & 0 \\
\hline & Apr 2013 & 0 & 100 & 0 & 0 & 0 \\
\hline & May 2013 & na & na & na & na & na \\
\hline
\end{tabular}

$\mathrm{S}$, average of the 3 surface sites; $\mathrm{P}$, average of the 2 depth sites; na, not available.
rDNA), the values increased, as expected $(0.130 \pm 0.076$ pg MC cell ${ }^{-1}$, respectively) (Tab. 5). Due to a snowfall during sampling, in December 2012 no sample was collected for molecular biology analysis and therefore it was not possible to verify whether the abnormally high cell quota was related to a population $100 \%$ composed of $m c y \mathrm{~B}^{+}$cells, or to other reasons. However, even in case of a $100 \%$ toxic population the cell quota would still be $\sim 10$ times higher than usual. Only assuming a possible contribution by $W$. naegeliana, the cell quota would be in the range of the other values, 0.010 and $0.013 \mathrm{pg} \mathrm{MC} \mathrm{cell}^{-1}$; however, this possibility is unlikely, based on what is known on Woronichinia toxicity. To see if the toxic fraction of $P$. rubescens population was a better predictor of $\mathrm{MC}$ concentration than the whole population, the fit of linear model between MC variants and the potentially toxic cells ( $m c y \mathrm{~B}^{+}$cells) was used, but the variability ex-

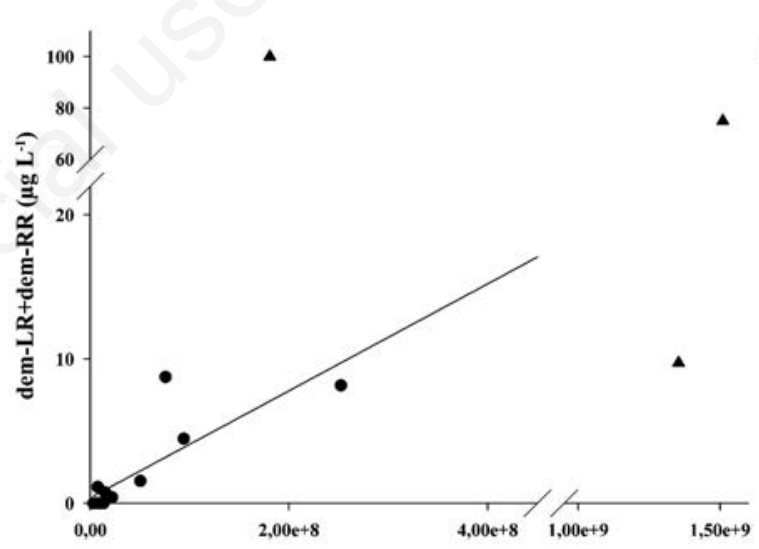

(a)

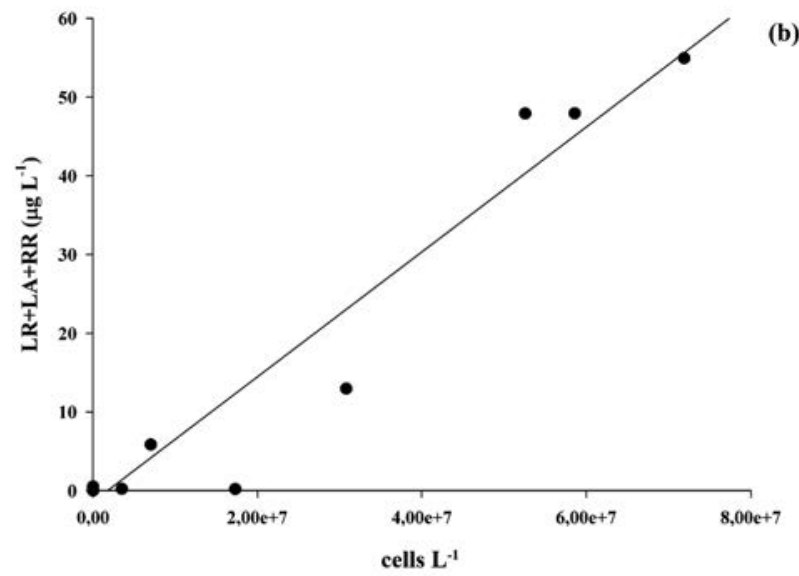

Fig. 6. a) Correlation between P. rubescens and MC-dem-LR + MC-dem-RR in integrated samples; the regression line is $\mathrm{Y}=3.71 \times 10^{-8}\left(\mathrm{SE} 8.18 \times 10^{-9}\right) \cdot \mathrm{X}+0.38(\mathrm{SE} 0.68) ; \mathrm{R}^{2}=0.67$, $\mathrm{P}<0.001$; data from May 2012 have been excluded from the regression. b) Correlation between M. botrys and MC-LR + MC-RR + MC-LA in integrated samples; the regression line is $\mathrm{Y}=7.94 \times 10^{-}$ ${ }^{7}\left(\right.$ SE $\left.5.44 \times 10^{-8}\right) \cdot \mathrm{X}+1.40($ SE 1.58$) \mathrm{R}^{2}=0.94 \mathrm{P}<0.001$. 
plained by the regression was much lower (54\% vs $81 \%$ ) (data not shown).

The cell quota calculated on the integrated samples were generally consistent with the average values determined in the discrete ones, except for the values obtained in May 2012 (Tab. 6), which were out of range. Indeed, the cell quota from the discrete sample was $0.069 \mathrm{pg} \mathrm{MC}$ cell $^{-1}$, whereas the one in R1 was almost 10 times higher $\left(0.554 \mathrm{pg} \mathrm{MC} \mathrm{cell}^{-1}\right)$ and in $\mathrm{R} 310$ times lower $(0.007 \mathrm{pg}$ $\mathrm{MC}$ cell $\left.^{-1}\right)$.

The cell quota of $M$. botrys in discrete samples averaged $0.771 \pm 1.280 \mathrm{pg} \mathrm{MC} \mathrm{cell}^{-1}$ (median $0.303 \mathrm{pg} \mathrm{MC}$ cell $^{-1}$ ) (Tab. 5); in the integrated samples cell quota averaged $0.668 \pm 0.495 \mathrm{pg} \mathrm{MC} \mathrm{cell}^{-1}$, very similar to the discrete sample values (Tab. 6).

\section{DISCUSSION}

Sardinia has a typical semiarid mediterranean climate, and relies for a $57 \%$ on a complex water distribution network of surface artificial reservoirs exploited for civilian, agricultural, and industrial purposes (ISRI, 2006), and accounting for about $90 \%$ when only drinking water is concerned (Lugliè et al., 2013). Therefore a good water management plan is essential. Most of the Sardinian reservoirs were eutrophic (Total Nitrogen, 594-2057 $\mu_{\mathrm{g} \mathrm{L}}^{-1}$; Total Phosphorus, 23-180 $\mu \mathrm{g} \mathrm{L}^{-1}$ ), with phytoplankton communities dominated by CB (Sechi and Lugliè, 1996; Begliutti et al., 2007; Marchetto et al., 2009). The Alto Flumendosa reservoir maintains an intermediate trophic level between oligotrophy and mesotrophy, as shown by the nutrient concentrations reported by Cabras et al. (2013) (Supplementary Tab. 2), which refer to the period of the monitoring activities described in this paper. The results reported in this latter work are consistent with other previous studies (Begliutti et al., 2007; Sulis et al., 2014).

Sulis et al. (2014), who used a very large chemical and phycological dataset for the Flumendosa-Campidano system to calibrate a model of water quality, described a variable phytoplankton community over the years (annual averages from 1996 to 2012), with a dominance of CB (>90\%) from 2002 onward. Our study, which was carried out between the end of 2011 and mid 2013 fully confirmed the dominance by $\mathrm{CB}$, although in terms of biomass other phytoplankton groups were also relevant. The species composition of the CB community in the Flumendosa reservoir has been previously described as dynamic, with alternating dominating species (Lugliè et al., 1997; Meregalli et al., 2002; Begliutti et al., 2007). As reported by Sulis et al. (2014), P. rubescens-agardhii has been continuosly dominant (>90\%) between 2002 and 2009 (peak density $35 \times 10^{6}$ cells $\mathrm{L}^{-1}$ ), then decreased to $\sim 20 \%$ of the whole phytoplankton community in 2010. Microcystis spp. has also been always present, generally at the onset

Tab. 4. ELISA and LC-MS/MS results for microcystins in fish tissues.

\begin{tabular}{|c|c|c|c|c|c|c|c|c|}
\hline \multirow[t]{2}{*}{ Date } & & \multirow{2}{*}{$\begin{array}{l}\text { ELISA } \\
\left(\mathrm{ng} \mathrm{g}^{-1}\right)\end{array}$} & \multicolumn{6}{|c|}{ LC-MS/MS (ng g-1) } \\
\hline & & & $\mathbf{R R}$ & dem-RR & LR & dem-LR & LA & TOT \\
\hline \multirow[t]{3}{*}{$08 / 11 / 11$} & Trout1 & 0.054 & nd & nd & nd & nd & nd & nd \\
\hline & Trout2 & 0.144 & nd & nd & Traces & Traces & nd & nd \\
\hline & Trout3 & 0.936 & nd & nd & Traces & Traces & nd & nd \\
\hline \multirow[t]{2}{*}{$28 / 02 / 12$} & Trout1 & 0.200 & nd & nd & nd & nd & nd & nd \\
\hline & Trout2 & 0.132 & nd & nd & Traces & Traces & nd & nd \\
\hline \multirow[t]{2}{*}{$24 / 04 / 12$} & Trout1 & 0.092 & nd & nd & nd & nd & nd & nd \\
\hline & Trout2 & $*$ & nd & nd & Traces & Traces & nd & nd \\
\hline $6 / 06 / 12$ & Juveniles & 0.048 & nd & nd & nd & nd & nd & nd \\
\hline \multirow[t]{2}{*}{$25 / 09 / 12$} & Trout1 & 0.046 & nd & nd & Traces & Traces & nd & nd \\
\hline & Trout2 & 0.152 & nd & nd & Traces & nd & nd & nd \\
\hline
\end{tabular}

*Lost sample; nd, not detected.

Tab. 5. Average of cell quota computed for different microcystins variants (pg cell ${ }^{-1}$ ) in $P$. rubescens and M. botrys in discrete samples (see text). Computations refer to the whole sampling period.

\begin{tabular}{|c|c|c|c|}
\hline & & Species & \\
\hline & P. rubescens & P. rubescens mcy $\mathrm{B}^{+}$ & M. botrys \\
\hline Discrete samples & $\begin{array}{c}0.104(0.055) 0.274 \\
\mathrm{n}=72\end{array}$ & $\begin{array}{c}0.130(0.128) 0.076 \\
\mathrm{n}=30\end{array}$ & $\begin{array}{c}0.771(0.303) 1.281 \\
\mathrm{n}=21\end{array}$ \\
\hline
\end{tabular}

Mean (median) SD. 
of the blooms, while Dolichospermum bloomed in 2003, but after that low densities were reported sporadically over the years (Sulis et al., 2014). The overall density of CB community during our study was about 10 times lower than what was observed before (Messineo et al., 2009; Sulis et al., 2014), but an even more complex alternation of species was observed. P. rubescens was always present and generally dominant until summer 2012, with the typical trend of depth blooms in summer and more homogeneous distribution along the water column during the other seasons (Kurmayer et al., 2016). These results confirmed the need to sample the metalimnetic layers, especially when they are the source of drinking water supply (Manganelli et al., 2010, 2016). The dominating species alternating with $P$. rubescens was $W$. naegeliana, previously described in the lake only in 1995 and 1996 (Meregalli et al., 2002). Blooms of $W$. naegeliana, particularly in late summer and autumn, are not infrequent in temperate lakes, and have been reported in Northern Europe (including Poland, the Czech Republic, Sweden, Finland, Belgium, Russia), North America (United States) and Australia (Komárek and Anagnostidis, 1999; Bucka and Wilk-Woźniak, 2002; Annadottér et al., 2005; RajaniemiWacklin et al., 2005). Furthermore, at the beginning of our study, $M$. botrys was the dominating species, then disappearing in the following months. In addition, D. planctonicum was never dominant but always present as supported by data from integrated samples on the $20 \mathrm{~m}$ water column, useful to detect the presence of CB species at low density. Since during the winter months $M$. botrys was undetectable also in the integrated samples, its re-appearance during the summer months can be explained considering that colonies overwintered on the bottom sediments (Reynolds et al., 1981).
We tested whether CB abundance could be a good proxy for MC concentration in the lake, as it has been shown by many studies on Planktothrix (Briand et al., 2005; Catherine et al., 2008; Dolman et al., 2012; Salmaso et al., 2014). A prerequisite for this relationship to be significant is the presence of a single dominant species (Salmaso et al., 2014). In the present study, the toxic species occurring simultaneously were compared with the different MC-variants, analysed separately. The pattern of MC variants was demonstrated to be highly dependent on the potentially producing species: highly significant linear regressions were obtained between $P$. rubescens and the demethylated form of MC-RR and MCLR, and between M. botrys and MC-LA and MC-LR, in both discrete and integrated samples. Each species was characterized by a different slope $(t$-test, $t=2.79, \mathrm{P}<0.01)$. The determination of linear regressions with the same slope in both type of samples, for each species, reinforces the validity of our results, since in the integrated samples values of cell density and MC concentration were well above the detection limits. In the elaboration of $P$. rubescens integrated data, results from May 2012 were not considered, being totally out of range. These results allowed to associate the potential producing species with the different $\mathrm{MC}$ variants and furthermore to obtain a model which explained more than $80 \%$ of the variation in $\mathrm{MC}$ concentration in this system. The association between P. rubescens and MC-dem-RR and -dem-LR was also confirmed by the 10 monoclonal isolated strains producing only the two variants, and is in line with data from other Italian lakes (Messineo et al., 2006; Manganelli et al., 2010, 2016).

Even if no correlation between MCs and W. naegeliana was found, we cannot definitely rule out its ability to pro-

Tab. 6. Cell quota of microcystins variants $\left(\mathrm{pg} \mathrm{cell}{ }^{-1}\right)$ in $P$. rubescens and $M$. botrys in integrated samples in the three sites.

\begin{tabular}{|c|c|c|c|c|}
\hline \multirow[t]{2}{*}{ Site } & \multirow[t]{2}{*}{ Date } & \multicolumn{3}{|c|}{ Species } \\
\hline & & P. rubescens & P. rubescens mcy $\mathrm{B}^{+}$ & M. botrys \\
\hline \multirow[t]{9}{*}{ R1 } & Oct 2011 & 0.000 & 0.000 & 0.911 \\
\hline & May 2012 & 0.554 & 1.152 & nd \\
\hline & Sept 2012 & 0.153 & na & 0.421 \\
\hline & Oct 2012 & 0.000 & 0.000 & 0.828 \\
\hline & Dec 2012 & 0.000 & 0.000 & nd \\
\hline & Jan 2013 & 0.031 & na & nd \\
\hline & Mar 2013 & 0.048 & 0.075 & nd \\
\hline & Apr 2013 & 0.032 & 0.057 & nd \\
\hline & May 2013 & 0.019 & 0.031 & nd \\
\hline \multirow[t]{4}{*}{ R2 } & Oct 2011 & 0.000 & 0.000 & 0.764 \\
\hline & May 2012 & 0.050 & 0.075 & 0.011 \\
\hline & Apr 2013 & 0.116 & 0.195 & nd \\
\hline & May 2013 & 0.050 & 0.070 & 1.526 \\
\hline \multirow[t]{2}{*}{ R3 } & Oct 2011 & 0.000 & 0.000 & 0.818 \\
\hline & May 2012 & 0.007 & 0.012 & 0.063 \\
\hline
\end{tabular}

na, not available; nd, not detected. 
duce some MC congener or other CTX. Since $W$. naegeliana was simultaneously detected with other toxic species, no conclusive considerations on its toxicity have been reported so far. Sivonen et al. (1990) reported that the neurotoxicity of bloom samples collected from Finnish lakes was associated statistically with Anabaena (Dolichospermum) lemmermannii, Anabaena (Dolichospermum) flos-aquae and W. naegeliana. In other studies, various microcystins were found during blooms in which W. naegeliana was dominant (Willame et al., 2005; Baudin et al., 2006), and the presence of mcy genes in environmental samples characterized by the presence of this species was also reported (Oberholster et al., 2006). However, up to now, there are no pure isolated cultures of $W$. naegeliana in the world cyanobacterial collection, and we also failed to maintain any culture after isolation.

With respect to Microcystis, and confirming our results on M. botrys, other studies in the field have observed significant correlations between the population abundances and MC concentrations (Wang et al., 2010; Horst et al., 2014, among others).

The strong relationship between $\mathrm{CB}$ and MC in $P$. rubescens implies a high stability of population genetic structure over time (Salmaso et al., 2014; Kurmayer et al., 2016), which is indeed what we found in the Flumendosa reservoir. But this is not always the case: in Lake Vico (Central Italy), where P. rubescens was dominant, the fraction of the $m c y \mathrm{~B}^{+}$cells was highly variable over time, especially during the blooms. In those conditions, the correlation between cell density and MC could explain only about $50 \%$ of MC variation (Manganelli et al., 2016). The quantification of $m c y$ genes of $P$. rubescens has been indicated as a better predictor of MC concentrations (Ostermaier and Kurmayer, 2010; Hautala et al., 2013). However, in this study the application of the linear regression to the $m c y \mathrm{~B}^{+}$cells and $\mathrm{MC}$ reduced the percentage of $\mathrm{MC}$ variation explained, from $>80 \%$ to $\sim 50 \%$, i.e., a value very close to what was observed by Briand et al. (2008) in a population of $P$. agardhii and consistent with what we previously described in Lake Vico (Manganelli et al., 2016). There are several possible explanations for this outcome, as summarized in Kurmayer et al. (2016), such as other coexisting non identified toxic species, problems in the amplification of $m c y$ genes or mutation inactivating $m c y$ genes. Or it could be also hypothesized that other factors, in addition to the genetic make up, influence the relationship between density and toxicity, and the relation between the whole population and MC, representing the environmental cell quota (ECQ, sensu Salmaso et al, 2014), includes those factors.

Since the relationship between MC content and the dynamics of the relative producer was quite strong, the slope of the linear regression could be a good estimate of the cell quota (Salmaso et al., 2014), reducing the variability due to extreme values. A reliable estimate of the content of MC per cell can be very important when the possible risk for the population has to be assessed when only the density of CB is known.

The 'average' density-based $P$. rubescens cell quota determined in this study were in the range of other values reported in literature (Naselli-Flores et al., 2007; Briand et al., 2008; Kosol et al., 2009; Manganelli et al., 2010, 2016). Interestingly, the cell quota determined for $M$. botrys were constantly about 10 times higher than $P$. rubescens and in the range of Microcystis cell quota in the field estimated by Yu et al. (2014) (0.001 and $1.326 \mathrm{pg}$ cell $^{-1}$ on the whole population and 0.012 and $1.876 \mathrm{pg}$ cell $^{-1}$ on the toxic cells). The high cell quota and the production of the more acutely toxic variants (MC-LA and MC-LR, showing the lowest $\mathrm{LD}_{50}$ values) make $M$. botrys a highly toxic species, whose dynamic should be carefully monitored from spring to fall, for possible surface blooms.

The levels of MC content during the study never exceeded $1 \mu \mathrm{g} \mathrm{L}^{-1}$ in all raw water discrete samples, excluding risk of acute and subchronic intoxication by drinking water for the population (WHO, 2004) and the domestic and wild animals (considering the action levels established by the California State EPA, for dairy cows, beef, cattles and dogs; Butler and Linville, 2012). Also the average cell quota was in the range of what is known for the $\mathrm{CB}$ species present. However, in the field some unpredictable events are possible (see May and December 2012) for which an exaggerated production of toxin per cell occurs (cell quota values up to 40 fold the average one in December) due to still unknown phenomena. The data used to compute these high values coincided with periods of high $\mathrm{MC}$ concentrations and $P$. rubescens density, making highly improbable the influence of measurement errors on the toxin quota estimates. A sudden increase in toxin concentration, in a time-frame of a few hours, has been observed in Microcystis in the field and in laboratory experiment, and it has been associated to the fast increase in cell density and to faster MC production rate (Wood et al., 2011, 2012). We speculate that the integrated sample could partly reproduce such a situation, since the ambient conditions of the cells change completely within few minutes, including a rapid increase of cell density. However, this explanation does not fit with the discrete December samples, as well as with the integrated R3 sample in May. This is definitely a field to explore, to define adequate strategies of management, since these situations are of particular concern when the risk for the exposed consumers has to be estimated.

The relatively low cell densities found in the monitoring period is consistent with the low MC contamination level found in trout muscle. The discrepancy between the ELISA and LC-MS/MS methods (estimated concentrations up to $0.9 \mathrm{ng} \mathrm{g}^{-1}$ and trace values, respectively) may 
be explained by multiple reasons: i) the matrix effects affecting the ELISA detection, interfering with the optical density detection; ii) the ELISA kit can reveal the presence of those MCs congeners for which analytical standard are not available for LC-MS/MS; and iii) the presence of conjugation products in fish tissue, which can cross-react with anti-MC antibodies. The trace levels detected by LC-MS/MS might be due to better compensation of matrix effects by the use of an appropriate calibration curve. However, low recovery of some MC variants could result to underestimation of $\mathrm{MC}$ concentrations in the muscle samples. In this respect, as pointed out by a review on the occurrence of cyanotoxins in food items (Testai et al., 2016a), the availability of reliable, validated methods for detecting MC in complex matrices is a priority to collect good quality data to be used in the estimation of the possible risk due to human consumption. In addition, in view of the variability in the rate of toxins production by the $\mathrm{CB}$ communities, and in order to have a reliable estimate of the average ingestion of potentially contaminated fish and shell-fish grown in a specific water body, it is necessary to measure cyanotoxin content in the edible parts of representative species. Furthermore, the sampling should be carried out over an adequate period of time to take into account seasonal variations in cyanotoxins production and possible differences among fish species depending on their diet, as well as on their capacity of retention/detoxication and elimination of cyanotoxin residues. It has indeed been shown that the bioaccumulation of MCs was species specific, with a tenfold higher bioaccumulation in catfish rather than in carp (Singh and Asthana, 2014).

\section{CONCLUSIONS}

Toxic cyanobacteria blooms can be a serious problem for the surface water distribution system in Sardinia. In the oligo-mesotrophic Flumendosa reservoir, toxic cyanobacteria were continuously present, although with relatively low densities and variations over time. Three different species were alternatively dominating, namely P. rubescens (producing the demethylated form of MCRR and MC-LR), M. botrys (producing MC-LR and -LA) and $W$. naegeliana (whose toxicity is still unknown). Particular attention should be paid to the not visible deep $P$. rubescens summer blooms, since they are located were water is taken for drinking water supply. M. botrys, although not detectable during winter, was abundant in summer, meaning that inocula of the population are always present and should be carefully monitored since it produces the most toxic variants with a high cell quota.

Our results show that due to the relatively low density of $\mathrm{CB}$ and limited $\mathrm{MC}$ concentration found in the lake during the study period, there is no immediate risk of ex- posure to $\mathrm{MC}$ for the human and animal population. However, a variable $\mathrm{CB}$ community, characterised by the persistence of a significant toxic fraction, and the evidence of spotted variable toxin production rates suggest the need to take the system under control to manage possible sudden changes in toxins concentrations. The validity of the linear model applied to separate $\mathrm{MC}$ variants, to be further verified, show the possibility to expand its use in more complex CB communities, to obtain slopes representative of the studied systems.

\section{ACKNOWLEDGMENTS}

We thank Dr Roberta Boi for helping in collecting field samples and Dr Valentina Rosu for the work done. The work was supported by a grant from the Ministero del Lavoro, della Salute e delle Politiche Sociali; Dipartimento per la Sanità Pubblica Veterinaria, la Nutrizione e la Sicurezza degli Alimenti, contract number IZS SA 04/10 RC. The funder had no role in study design, data collection and analysis, decision to publish, or preparation of the manuscript. The Authors wish to thank the European Cooperation in Science and Technology COST Action ES1105 CYANOCOST for networking and knowledge-transfer support.

Thanks to three anonymous reviewers who greatly improved the manuscript.

\section{REFERENCES}

Annadottér H, Cronberg G, Nystrand R, Rylander R, 2005. Endotoxins from cyanobacteria and Gram-negative bacteria as the cause of an acute influenza-like reaction after inhalation of aerosols. EcoHealth. 2:209-221.

Aktan Y, Lugliè A, Sechi N, 2009. Morphological plasticity of dominant species in response to nutrients dynamics in Bidighinzu Reservoir of Sardinia, Italy. Turk. J. Fish Aq. Sci. 9:137-144.

Baudin I, Cagnard O, Grandguillaume JJ, Do-Quang Z, 2006. Algae and associated toxins \& metabolites: methodology for risk assessment and risk management. Water. Pract. Technol. 4:1-12.

Begliutti B, Buscarinu P, Marras G, Sechi GM, Sulis A, 2007. Reservoirs water-quality characterization for optimization modelling under drought conditions. Part I - reservoirs trophic state characterization, p. 239-261. In: G. Rossi, T. Vega and B. Bonaccorso (eds.), Methods and tools for drought analysis and management. Springer, Dordrecht.

Berry J, 2013. Cyanobacteria toxins in food-webs: implications for human and environmental health, p. 531-589. In: A. Rodriguez-Morales (ed.), Current topics in public health.

Botti P, Dessena MA, Fiori M, Grillo SM, Marcello A, Matzuzzi C, Pretti S, Vacca S, 2001. The Medio Flumendosa reservoir. Rendiconti Seminario Facoltà Scienze Università Cagliari Supplemento 71:209-220.

Briand E, Gugger M, Francois JC, Bernard C, Humbert JF, Quiblier C, 2008. Temporal variations in the dynamics of 
potentially microcystin-producing strains in a bloom-forming Planktothrix agardhii (cyanobacterium) population. App. Environ. Microbiol. 74:3839-3848.

Briand JF, Jacquet S, Bernard C, Humbert JF, 2003. Health hazards for terrestrial vertebrates from toxic cyanobacteria in surface water ecosystems. Vet. Res. 34:361-377.

Briand JF, Jacquet S, Flinois C, Avois-Jacquet C, Maisonnette C, Leberre B, Humbert JF. 2005. Variations in the microcystin production of Planktothrix rubescens (cyanobacteria) assessed from a four-year survey of Lac du Bourget (France) and from laboratory experiments. Microb. Ecol. 50:418-428.

Bucka H, Wilk-Woźniak E, 2002. A monograph of cosmopolitan and ubiquitous species among pro- and eukaryotic algae from water bodies in Southern Poland. Karol Starmach Institute of Freshwater Biology, Polish Academy of Sciences, Kraków.

Buratti FM, Manganelli M, Vichi S, Stefanelli M, Scardala S, Testai E, Funari E, 2017. Cyanotoxins: producing organisms, occurrence, toxicity, mechanism of action and human health toxicological risk evaluation. Arch. Toxicol. 91:1049-1130.

Buratti FM, Scardala S, Funari E, Testai E, 2011. Human glutathione transferases catalyzing the conjugation of the hepatoxin microcystin-LR. Chem. Res. Toxicol. 24:926-933.

Butler NCJ, Linville R, 2012. Toxicological summary and suggested action levels to reduce potential adverse health effects of six cyanotoxins. Office of Environmental Health Hazard Assessment, California Environmental Protection Agency, Sacramento.

Cabras PA, Rolesu S, Orrù A, Salati F, Pintore A, Garau P, Funari E, Lanni L, Vodret B, 2013. [Sviluppo di un modello di analisi del rischio di contaminazione da cianotossine in occasione di fioriture di cianobatteri tossici, ed eventuali riflessi sulle popolazioni animali domestiche e selvatiche e sull'ittiofauna di un lago della Sardegna (lago Alto Flumendosa)].[Report In Italian]. Ministero della Salute; Dipartimento per la Sanità Pubblica Veterinaria, la Nutrizione e la Sicurezza degli Alimenti.

Carbis CR, Waldron DL, Mitchell GF, Anderson JW, McCauley I, 1995. Recovery of hepatic function and latent mortalities in sheep exposed to the blue-green alga Microcystis aeruginosa. Vet. Rec. 137(1):12-15.

Catherine A, Quiblier C, Yepremian C, Got P, Groleau A, Vincon-Leite B, Bernard C, Troussellier M, 2008. Collapse of a Planktothrix agardhii perennial bloom and microcystin dynamics in response to reduced phosphate concentrations in a temperate lake. FEMS Microbiol. Ecol. 65 (1):61-73.

Codd GA, Edwards C, Beattie KA, Barr WM, Gunn GJ, 1992. Fatal attraction to cyanobacteria? Nature 359:110-111.

Dolman AM, Rücker J, Pick FR, Fastner J, Rohrlack T, Mischke U, Wiedner C, 2012. Cyanobacteria and Cyanotoxins: The Influence of Nitrogen versus Phosphorus. PLoS One 7:e38757.

Ernst B, Neser S, O’Brien E, Hoeger SJ, Dietrich DR, 2006. Determination of the filamentous cyanobacteria Planktothrix rubescens in environmental water samples using an image processing system. Harmful algae 5:281-289.

Frazier K, Colvin B, Styer E, Hullinger G, Garcia R, 1998. Microcystin toxicosis in cattle due to overgrowth of blue-green algae. Vet. Hum. Toxicol. 40:23-24.

Funari E, Testai E, 2008. Human health risk assessment related to cyanotoxins exposure. Crit. Rev. Toxicol. 38:97-125.

Hallegraeff GM, Anderson DM, Cembella AD, 2004. Manual on harmful marine microalgae - Monographs on oceanographic methodology 11. Unesco, Paris: 793 pp.

Hautala H, Lamminmaki, U, Spoof L, Nybom S, Meriluoto J, Vehniainen M, 2013. Quantitative PCR detection and improved sample preparation of microcystin-producing $A n$ abaena, Microcystis and Planktothrix. Ecotoxicol. Environ. Saf. 87:49-56.

Hilborn ED, Beasley Val R, 2015. One health and cyanobacteria in freshwater systems: animal illnesses and deaths are sentinel events for human health risks. Toxins. 71374-1395.

Holm-Hansen O, Lorenzen CJ, Holmes RW, Strickland JDH, 1965. Fluorometric determination of chlorophyll. J. Cons. Perm. Int. Explor. Mer. 30:3-15.

Horst GP, Sarnelle O, White JD, Hamilton SK, Kaul RB, Bressie JD, 2014. Nitrogen availability increases the toxin quota of a harmful cyanobacterium, Microcystis aeruginosa. Wat. Res. 54:188-198.

Ibelings BW, Chorus I, 2007. Accumulation of cyanobacterial toxins in freshwater "seafood" and its consequences for public health, a review. Environ. Pollut. 150:177-192.

ISRI, 2006. [Le risorse idriche in Sardegna. Aggiornamento della valutazione intermedia].[in Italian]. Programma Operativo della Regione Autonoma della Sardegna.1.

Jespersen AM, Christoffersen K, 1987. Measurements of Chl-a from phytoplankton using ethanol as extraction solvent. Arch. Hydrobiol. 109: 445-454.

Komárek J, Anagnostidis K, 1999. [Cyanoprokaryota, 1: Chroococcales]. In: H. Ettl, G. Gardner, H. Heynig, D. Mollenheuer (eds.), [Süsswasserflora von Mitteleuropa].[Book in German]. Gustav Fischer, Jena: 548 pp.

Komárek J, Anagnostidis K, 2005. [Cyanoprokaryota, 2: Oscillatoriales]. In: B. Büdel, L. Krienitz, G. Gärtner, M. Schager (eds.), [Süsswasserflora von Mitteleuropa].[Book in German]. Elsevier, Jena: 759 pp.

Komárek J, Zapomělová E, 2007. Planktic morphospecies of the cyanobacterial genus Anabaena= subg. Dolichospermum 1. part: coiled types. Fottea, Olomouc 7:1-31.

Kosol S, Schmidt J, Kurmayer R, 2009. Variation in peptide net production and growth among strains of the toxic cyanobacterium Planktothrix spp. Eur. J. Phycol. 44:49-62.

Kurmayer R, Deng L, Entfellner E, 2016. Role of toxic and bioactive secondary metabolites in colonization and bloom formation by filamentous cyanobacteria Planktothrix. Harmful Algae 54:69-86.

Loizzo A, Sechi N, Volterra L, Contu A, 1988. Some features of a bloom of Oscillatoria rubescens D.C. registered in two Italian reservoirs. Wat. Air Soil Pollut. 38:263-271.

Lopez Rodas V, Costas E, 1999. Preference of mice to consume Microcystis aeruginosa (toxin-producing cyanobacteria): a possible explanation for numerous fatalities of livestock and wildlife. Res. Vet. Sci. 67:107-110.

Lugliè A, Gesuina L, Manca B, Sechi N, 1997. [Studi limnologici sul Lago Alto Flumendosa (Sardegna centrale): stato trofico e fitoplancton].[Article in Italian]. Boll. Soc. Sarda Sci. Nat. 31:83-100.

Lugliè A, Padedda BM, Bazzoni AM, Caddeo T, Casiddu P, Farina $\mathrm{P}$, Lai G, Manca B, Mariani MA, Pulina S, Satta CT, Stacca D, Sechi N, 2013. [Aspetti dell'ecologia dei sistemi acquatici della Sardegna e loro principali problematiche]. [Article in Italian]. Proceedings Assemblea Generale e del 
Symposium I Mari delle Isole (Resèaux d'Excellence des Territoires Insulaires - RETI): 8 pp.

Manganelli M, Scardala S, Stefanelli M, Vichi S, Mattei D, Bogialli S, Ceccarelli P, Corradetti E, Petrucci I, Gemma S, Testai E, Funari E, 2010. Health risk evaluation associated to Planktothrix rubescens: An integrated approach to design tailored monitoring programs for human exposure to cyanotoxins. Wat. Res. 44:1297-1306.

Manganelli M, Stefanelli M, Vichi S, Andreani P, Nascetti G, Scialanca F, Scardala S, Testai E, Funari E, 2016. Cyanobacteria biennal dynamic in a volcanic mesotrophic lake in central Italy: Strategies to prevent dangerous human exposures to cyanotoxins. Toxicon 115:28-40.

Marchetto A, Padedda BM, Mariani MA, Lugliè A, Sechi N, 2009. A numerical index for evaluating phytoplankton response to changes in nutrient levels in deep Mediterranean reservoirs. J. Limnol. 68:106 121.

Mariani MA, Padedda BM, Kaštovský J, Buscarinu P, Sechi N, Virdis T, Lugliè A, 2015. Effects of trophic status on microcystin production and the dominance of cyanobacteria in the phytoplankton assemblage of Mediterranean reservoirs. Sci. Rep. 5:1-16.

Meregalli M, Trebeni F, Manca B, Lugliè A, 2002. [Stato trofico e fitoplancton nel lago Alto Flumendosa].[Article in Italian]. Atti Associazione Italiana Oceanografia Limnologica 15:87-96.

Messineo V, Mattei D, Melchiorre S, Salvatore G, Bogialli S, Salzano R, Mazza R, Capelli G, Bruno M, 2006. Microcystin diversity in a Planktothrix rubescens population from Lake Albano (Central Italy). Toxicon 48:160-174.

Messineo V, Bogialli S, Melchiorre S, Sechi N, Lugliè, Antonella GL, Casiddu P, Mariani MA, Padedda BM, Di Corcia A, Mazza R, Carloni E, Bruno M, 2009. Cyanobacterial toxins in Italian freshwaters. Limnol. Ecol. Manag. Inl. Waters 39:95-106.

Moreira C, Vasconcelos V, Antunes A, 2013. Phylogeny and biogeography of cyanobacteria and their produced toxins. Mar. Drugs 11:4350-4369.

Naselli-Flores L, Barone R, Chorus I, Kurmayer R, 2007. Toxic cyanobacterial blooms in reservoirs under a semiarid Mediterranean climate: The magnification of a problem. Environ. Toxicol. 22:399-404.

Oberholster PJ, Botha A-M, Cloete TE, 2006. Toxic cyanobacterial blooms in a shallow, artificially mixed urban lake in Colorado, USA. Lakes \& Reservoirs 11:111-123.

Ostermaier V, Kurmayer R, 2009. Distribution and abundance of nontoxic mutants of cyanobacteria in lakes of the Alps. Microb. Ecol. 58:323-333.

Ostermaier V, Kurmayer R, 2010. Application of real-time PCR to estimate toxin production by the cyanobacterium Planktothrix sp. Appl. Environ. Microbiol. 76:3495-3502.

Paerl HW, Paul VJ, 2012. Climate change: Links to global expansion of harmful Cyanobacteria. Wat. Res. 46:1349-1363.

Papadimitriou T, Kagalou I, Leonardos ID, 2012. Seasonally accumulation of microcystins in the various tissues of an endemic and protected fish species (Rutilus panosi) with different sizes. Clean Soil Air Water 40:402-407.

Pellegrini S, Grilli Caiola M, Sechi N, 1995. Microcystis from Lake Liscia (Sardinia - Italy). Paper presented at the $8^{\text {th }}$ VIII Int. Symp. Phototrophic Prokaryotes Abstract, Urbino.

Planas D, Paquet S, 2016. Importance of climate change-phys- ical forcing on the increase of cyanobacterial blooms in a small, stratified lake. J. Limnol. 75:201-214.

Pulina S, Padedda BM, Sechi N, Lugliè A, 2011. The dominance of cyanobacteria in Mediterranean hypereutrophic lagoons: a case study of Cabras Lagoon (Sardinia, Italy). Scientia Marina 75:111-120.

Rajaniemi-Wacklin P, Rantala A, Mugnai MA, Turicchia S, Ventura S, Komárková J, Lepistö L, Sivonen K, 2005. Correspondence between phylogeny and morphology of Snowella spp. and Woronichinia Naegeliana, cyanobacteria commonly occurring in lakes. J. Phycol. 42:226-232.

Rantala A, Rajaniemi-Wacklin P, Lyra C, Lepistö L, Rintala J, Mankiewicz-Boczek J, Sivonen K, 2006. Detection of microcystin-producing cyanobacteria in Finnish lakes with genus-specific microcystin synthetase gene E (mcyE) PCR and associations with environmental factors. Appl. Environ. Microbiol. 72:6101-6110.

Reynolds CS, Jaworsky GHM, Cmiech HA, Leedale GF, 1981. On the annual cycle of the blue-green algae Microcystis aeruginosa Kütz. emend. Elenkin. Philos. T. R. Soc. B 293:419-477.

Rippka R, 1988. Isolation and purification of cyanobacteria. Method Enzymol. 167:3-27.

Saker ML, Jungblut AD, Neilan BA, Rawn DFK, Vasconcelos VM, 2005. Detection of microcystin synthetase genes in health food supplements containing the freshwater cyanobacterium Aphanizomenon flos-aquae. Toxicon 46:555-562.

Salmaso N, Copetti D, Cerasino D, Shams S, Capelli C, Boscaini A, Valsecchi A, Pozzoni F, Guzzella L, 2014. Variability of microcystin cell quota in metapopulations of Planktothrix rubescens: causes and implications for water management. Toxicon 90:82-96.

Sechi GM, Sulis A, 2009. Water system management through a mixed optimization-simulation approach. J. Wat. Resour. Plan. Manag. 135:160-170.

Sechi N, Lugliè A, 1992. Limnological studies on man-made lakes in Sardinia (Italy). Mem. Ist. It. Idrobiol. 50:365-381.

Sechi N, Lugliè A, 1996. Phytoplankton in Sardinian reservoirs. G. Bot. Ital. 130:977-994.

Sedmak B, Eleršek T, Grach-Pogrebinsky O, Carmeli S, Sever N, Lah TT, 2008. Ecotoxicologically relevant cyclic peptides from cyanobacterial bloom (Planktothrix rubescens) - a threat to human and environmental health. Radiol. Oncol. 42:102-113.

Singh S, Asthana, R, 2014. Assessment of microcystin concentration in carp and catfish: a case study from Lakshmikund pond, Varanasi, India. Bull. Environ. Contam. Toxicol. 92:687-692.

Sivonen K, Niemelä SI, Niemi RM, Lepistö L, Luoma TH, Räsänen LA, 1990. Toxic cyanobacteria (blue-green algae) in Finnish fresh and coastal waters. Hydrobiologia 3:256-275.

Stewart I, Seawright AA, Shaw GR, 2008. Cyanobacterial poisoning in livestock, wild mammals and birds - an overview, p. 611-637. In: H.K. Hudnell (ed.), Cyanobacterial harmful algal blooms - State of the science and research needs. Springer, Dordrecht.

Sulis A, Buscarinu P, Soru O, Sechi GM, 2014. Trophic state and toxic cyanobacteria density in optimization modeling of multi-reservoir water resource systems. Toxins (Basel) 6:1366-1384. 
Testai E, Buratti FM, Funari E, Manganelli M, Vichi S, Arnich N, Biré R, Fessard V, Sialehaamoa A, 2016a. Review and analysis of occurrence, exposure and toxicity of cyanobacteria toxins in food. EFSA supporting publication 2016: EN-998. 309 pp. Available at: http://www.efsa.europa.eu/sites/default/files/ scientific output/files/main documents/998e.pdf

Testai E, Scardala S, Vichi S, Buratti FM, Funari E, 2016b. Risk to human health associated with the environmental occurrence of cyanobacterial neurotoxic alkaloids anatoxins and saxitoxins. Crit. Rev. Toxicol. 29:1-35.

Utermhöl H, 1958. [Zur Vervollkhung der quantitativen Phytoplanktonmethodik].[Article in German]. Mitt. Int. Verein. Theor. Angew. Limnol. 9:1-38.

Vaitomaa J, Rantala A, Halinen K, Rouhiainen L, Tallberg P, Mokelke L, Sivonen K, 2003. Quantitative real-time PCR for determination of microcystin synthetase gene $\mathrm{E}$ copy numbers for Microcystis and Anabaena in lakes. Appl. Environ. Microbiol. 69:7289-7297.

Vichi S, Lavorini P, Funari E, Scardala S, Testai E, 2012. Contamination by Microcystis and microcystins of blue-green algae food supplements (BGAS) on the Italian market and possible risk for the exposed population. Food Chem. Toxicol. 50:4493-4499.

Walsby AE, Avery A, 1996. Measurement of filamentous cyanobacteria by image analysis. J. Microbiol. Meth. 26: 11-20.

Wang Q, Niu Y, Xie P, Chen J, Ma Z, Tao M, Qi M, Wu L, Guo
L, 2010. Factors affecting temporal and spatial variations of microcystins in Gonghu Bay of Lake Taihu, with potential risk of microcystin contamination to human health. TheScientificWorldJo 10:1795-1809.

Whitton BA (ed.), 2012. Ecology of Cyanobacteria II. Their Diversity in Space and Time. Springer, Dordrecht: $760 \mathrm{pp}$.

WHO, 2004. Guidelines for drinking water quality. 1. Recommendations. World Health Organization, Geneva.

Willame R, Jurczak T, Iffly JF, Kull T, Meriluoto J, Hoffmann $\mathrm{L}, 2005$. Distribution of hepatotoxic cyanobacterial blooms in Belgium and Luxembourg. Hydrobiologia 551:99-117.

Wood R, 2016. Acute animal and human poisonings from cyanotoxin exposure - A review of the literature. Environ. Int. 91:276-282.

Wood SA, Dietrich DR, Cary SC, Hamilton DP, 2012. Increasing Microcystis cell density enhances microcystin synthesis: a mesocosm study. Inland Waters 2:17-22.

Wood SA, Rueckert A, Hamilton DP, Cary SC, Dietrich DR, 2011. Switching toxin production on and off: intermittent microcystin synthesis in a Microcystis bloom. Environ. Microbiol. Rep. 3:118-124.

Yu G, Zhu M, Li R, Tan W, Jiang Y, Song G, 2014. Variation of Microcystis and microcystins coupling nitrogen and phosphorus nutrients in Lake Erhai, a drinking-water source in Southwest Plateau, China. Environ. Sci. Pollut. Res. Int. 21:9887-9898. 